\title{
A virus-like agent associated with neurofibromatosis in damselfish
}

\author{
M. C. Schmale ${ }^{1, *}$, P. D. L. Gibbs ${ }^{1}$, C. E. Campbell ${ }^{2}$ \\ ${ }^{1}$ Rosenstiel School of Marine and Atmospheric Science,University of Miami, 4600 Rickenbacker Causeway, Miami, \\ Florida 33149, USA \\ ${ }^{2}$ Centers for Disease Control and Prevention, Atlanta, Georgia 30333, USA
}

\begin{abstract}
Damselfish neurofibromatosis (DNF) is a transmissible disease involving neurofibromas and chromatophoromas affecting bicolor damselfish Stegastes partitus on Florida reefs. Analysis of genomic DNA by Southern blotting techniques demonstrated the presence of a group of extrachromosomal DNAs in tumors from fish affected with DNF but not in healthy individuals. Cell lines obtained from tumors contained identical DNAs and were shown to be tumorigenic in vivo, while lines established from healthy fish did not contain such DNA and were not tumorigenic. These DNA patterns were also observed in experimentally induced tumors. A DNase resistant component of this DNA was isolated from both tumor cells and conditioned media of tumor cell lines suggesting that these sequences were encapsulated in viral particles. These data support the hypothesis that one or more of these extrachromosomal DNA forms is the genome of an unusual virus and that this virus is the etiologic agent of DNF. We have tentatively termed this agent the damselfish virus-like agent (DVLA).
\end{abstract}

KEY WORDS: Neurofibroma $\cdot$ Damselfish $\cdot$ Tumor $\cdot$ Virus $\cdot$ Schwann Cell $\cdot$ Chromatophore

\section{INTRODUCTION}

Viruses capable of inducing tumors have proved to be invaluable tools in the study of molecular mechanisms of neoplastic transformation of cells. A wide variety of oncogenic viruses have been identified in mammals and birds, primarily from the Retroviridae family and from 5 families of DNA viruses: Polyomaviruses, Papillomaviruses, Adenoviruses, Herpesviruses and Hepadnaviruses (Tooze 1980, Fan 1994). These viruses have been indispensable for experimental manipulations of tumorigenesis in a variety of cell types. Several oncogenic viruses, primarily retroviruses, have been described from fishes (Poulet et al. 1994). At least one of these viruses, walleye dermal sarcoma virus, may represent a novel group of retroviruses and may induce tumor formation by a previously unknown mech-

*E-mail: mschmale@rsmas.miami.edu anism, expression of retroviral encoded D-type cyclin homologs (Holzschu et al. 1995, LaPierre et al. 1998).

The majority of tumors caused by DNA viruses and retroviruses are papillomas, sarcomas, lymphomas and leukemias (Fan 1994). No transmissible tumors have been identified which involve cells derived from the embryonic neural crest, including neurons, Schwann cells, other glial cell types or melanophores. Damselfish neurofibromatosis (DNF) is apparently the only reported example of a naturally occurring transmissible tumor involving neuroectodermal cell types. DNF is a disease affecting bicolor damselfish Stegastes partitus on Florida reefs which is characterized by multiple neurofibromas, neurofibrosarcomas and chromatophoromas (Schmale et al. 1983, 1986). The primary cell types found in these tumors include Schwann cells and chromatophores (including melanophores). These tumors can be transmitted via intramuscular (IM) injection of cell-free tumor homogenates $(0.22 \mu \mathrm{m}$ filtrates), as well as by injection of cells from tumor cell 
lines maintained in culture for many years, indicating that DNF is caused by a sub-cellular infectious agent (Schmale 1995). We have previously demonstrated the presence of several retroviruses in damselfish cell lines (Schmale et al. 1996 and unpubl. data). However, retroviral genomes could not be detected consistently in damselfish tumors or other tissues and thus cannot be considered a likely etiologic agent of this disease.

In this study we report the occurrence of a group of extrachromosomal DNAs (eDNA) in tumors from fish affected with DNF but not in healthy individuals. We have determined the distribution of this eDNA in both tumor bearing and healthy fish, and cell lines derived from such fish, and conducted in vivo transmission studies to investigate the relationship of these DNAs to tumorigenesis. We have also assessed resistance to DNase treatment as an indicator of possible encapsulation of this eDNA into intra- or extracellular particles.

\section{MATERIALS AND METHODS}

Damselfish and cell cultures. Bicolor damselfish Stegastes (previously Pomacentrus) partitus were collected on reefs in South Florida which had previously been surveyed to determine disease prevalence rates (Schmale 1991). Healthy fish used for experimental tumor induction were collected from a single low disease prevalence reef, Fowey Rocks. Fish were maintained in either recirculating or flow-through marine aquaria of $\geq 35 \mathrm{l}$ at $20-30^{\circ} \mathrm{C}$. Normal fish were observed in the laboratory for several weeks following capture to confirm initial observations that they lacked any signs of DNF. DNF was identified by visual inspection for external tumors as described in Schmale et al. (1986). Spontaneous tumors were obtained from fish with DNF collected in the wild. Fish were euthanized using MS-222 (tricaine methanesulfonate, Argent Labs) at a dosage of $180 \mathrm{mg} \mathrm{l}^{-1}$ and tumors were collected using aseptic procedures.

Damselfish cell lines were derived from one of the following: naturally occurring tumors (Lines 89-05, 92-16 and 96-24), experimentally induced tumors (Lines 88-503, 86-583 and 89-734), embyros from healthy fish (Lines FE1 and FE2), brain from healthy fish (FB3), or fins from healthy fish (Lines 22A, 23A, 63L). Primary cultures were established and maintained as described previously by Schmale et al. (1994). Cell lines were obtained by selection of primary cultures by repeated subculturing. In addition, Lines $22 \mathrm{~A}, 23 \mathrm{~A}$ and $63 \mathrm{~L}$ were obtained by infection of primary cultures of fin tissue from healthy fish with cellfree $(0.22 \mu \mathrm{m}$ filtered) conditioned media from the 8905 or 86-583 cell lines containing retroviral particles (authors' unpubl. data).
Experimental induction of tumors. Tumorigenicity of various preparations of tumor and normal tissues and cultured cells was assessed by IM injection into normal, healthy, bicolor damselfish (for further details see Schmale 1995). Briefly, healthy fish were lightly anesthetized with $120 \mathrm{mg} \mathrm{ml}^{-1} \mathrm{MS}-222$ at $\mathrm{pH} 8$ before IM injectection. Approximately 20-50 $\mathrm{ll}$ (depending on size of fish) of either tumor homogenate or cultured cells were injected at each of 2 sites slightly above the lateral line on opposite flanks of the fish. Tumor homogenates were prepared by homogenizing tumor tissues in Hanks' balanced salt solution (HBSS) without $\mathrm{Ca}^{+2}$ or $\mathrm{Mg}^{+2}$ (GIBCO) or L-15 medium (GIBCO) at a concentration of $80 \mathrm{mg} \mathrm{ml}^{-1}$ using a glass homogenizer on ice (as described in Schmale \& Hensley 1988). Cultured cells were harvested by trypsinization and resuspended in HBSS at a concentration of approximately $5 \times 10^{6}$ cells ml$^{-1}$ for injection.

Tumor development was scored upon the appearance of a small hyperpigmented spot or raised area on the skin near the injection site with final confirmation dependent on the subsequent development of a conspicuous tumor at that site. A subset of these tumors was collected for additional confirmation by histological examination (see Schmale 1995). Injected fish were observed for the presence of externally visible lesions at weekly intervals for $8 \mathrm{wk}$ following injection and at monthly intervals thereafter for at least $1 \mathrm{yr}$. The use of a 1 yr time interval was based on experience from previous studies run for longer periods that had indicated that the majority of fish which develop tumors in laboratory experiments do so within 1 yr of injection (Schmale \& Hensley 1988). Fish were euthanized for harvest of tissues at 12 mo post-injection, at any time post-tumor development if it occurred earlier, or if they exhibited impaired feeding or swimming behavior.

DNA extraction and DNase treatment. DNA was extracted from all samples using a Proteinase K/SDS/EDTA digestion at $55^{\circ} \mathrm{C}$ followed by phenol, chloroform, isoamyl alcohol extraction and precipitation in isopropanol (Sambrook et al. 1989). Extrachromosomal DNA was prepared by excision of appropriate molecular weight fractions from genomic DNA separated on $1 \%$ agarose gels. Gel slices were frozen and re-precipitated, and agarose was then removed by spun column with siliconized glass. Selected samples were digested with DNase I (Roche Diagnostics) at $80 \mathrm{U} \mathrm{ml}^{-1}$ at $37^{\circ} \mathrm{C}$ for $2 \mathrm{~h}$. A plasmid DNA (Bluescript, Stratagene), containing a $500 \mathrm{bp}$ insert derived from the $1.4 \mathrm{~kb}$ form of eDNA from the 92-16 cell line, was added to all DNase treated samples at $0.06 \mu \mathrm{g} \mathrm{ml}^{-1}$ as a control for complete digestion. For DNase analysis, homogenates of cultured tumor cells were prepared using a Polytron homogenizer and clarified by centrifugation at $16000 \times g$ for $20 \mathrm{~min}$. Conditioned media 
was collected from tumor cell cultures, clarified by centrifugation at $16000 \times g$ for $1 \mathrm{~h}$ followed by pelleting of samples at $190000 \times g$ for $2 \mathrm{~h}$.

DNA cloning and detection. A $1.4 \mathrm{~kb}$ DNA fragment was excised from ethidium bromide stained agarose gels containing undigested genomic DNA from the 9216 tumor-derived cell line (Fig. 1) and ligated to a Bluescript plasmid DNA. A cDNA library was created in a $\lambda$ gt10 vector (Stratagene) from polyA RNA isolated from pooled tumor tissues. Gel purified $1.4 \mathrm{~kb}$ DNA from the 92-16 cell line was initially used as a probe to identify homologous genomic and cDNA clones. Probe DNA was labeled using a random primed DNA labeling kit (Roche) with ${ }^{32} \mathrm{P}$-dCTP. Positive clones were sequenced and used to design primers to amplify intervening regions of genomic DNA. Primers used in the present study included: 5BU-5' TCG TCA CCA CCC ACT AAT CTA TC, 5AL-5' AAC GAT TAT CTC CAC CTA TGT CT, 5AU-5' CAG ACA TAG GTG GAG ATA ATC GT. Primers were also designed from the damselfish $\beta$-actin sequence to generate probes to serve as controls for detection of a single copy gene in Southern blots: SK21-5' CCC AAG AAG GAA GGC TGG AA

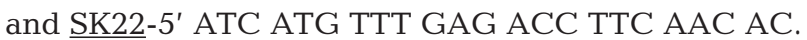

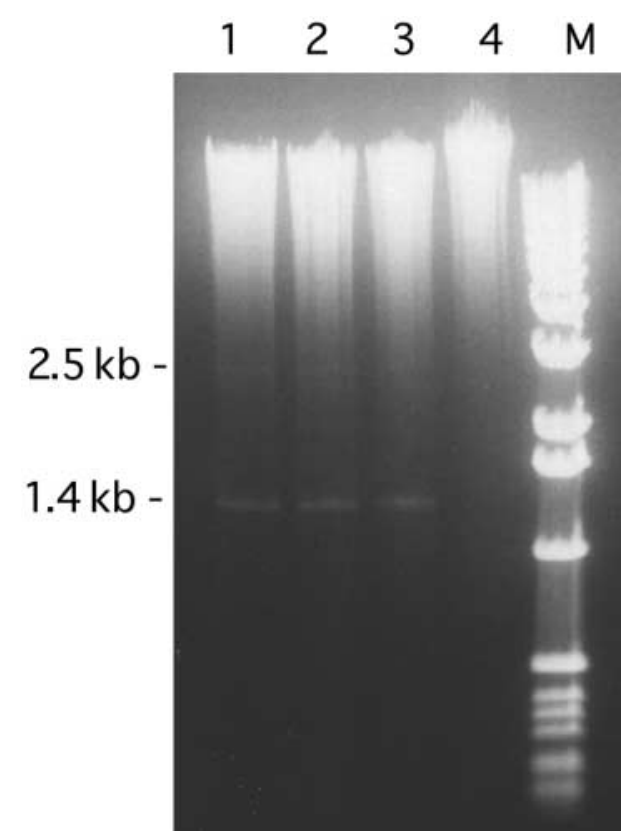

Fig. 1. Initial detection of extrachromosomal DNA (eDNA) as faint bands in gels containing undigested genomic DNA stained with ethidium bromide. One group of cultures from a cell line, 92-16, derived from a spontaneous neurofibroma produced large quantities of $1.4 \mathrm{~kb}$ DNA and, at lower levels $2.6 \mathrm{~kb}$ DNA. This feature could be repeatedly identified in this group of cultures (Lanes 1,2,3) but not in another group (Lane 4) of this line. Lanes 1 to 4: $10 \mu \mathrm{g}$ DNA pre-treated with RNaseA; M: $1 \mathrm{~kb}$ molecular weight ladder
For PCR reactions, $1 \mu \mathrm{g}$ of total DNA was amplified with $1 \mu$ Thermophilic Buffer (Promega), $10 \mathrm{mM}$ dNTPs, $25 \mathrm{mM} \mathrm{MgCl}_{2}$, and 1 pM primers with $1 \mathrm{U}$ of Taq polymerase (Promega) added after denaturation of samples for $5 \mathrm{~min}$ at $95^{\circ} \mathrm{C}$. PCR conditions were $94^{\circ} \mathrm{C}$ for $30 \mathrm{~s}$ denaturation, $60^{\circ} \mathrm{C}$ for $30 \mathrm{~s}$ annealing and $72^{\circ} \mathrm{C}$ for $1 \mathrm{~min}$ extension. After 30 cycles, the products were extended at $72^{\circ} \mathrm{C}$ for $10 \mathrm{~min}$. For RT-PCR analyses, total RNA was isolated from the 92-16 cell line using RNA-zol (Life Technologies). Five $\mu$ g of total RNA was added to $2.5 \mathrm{pmol}$ of a single primer and denatured at $70^{\circ} \mathrm{C}$ for $10 \mathrm{~min}$. Moloney Murine Leukemia Virus Reverse Transcriptase (MMLV-RT) buffer (50 mM Trizma- $\mathrm{HCl}, \mathrm{pH} 8.3,75 \mathrm{mM} \mathrm{KCl}, 3 \mathrm{mM} \mathrm{MgCl}_{2}$, and

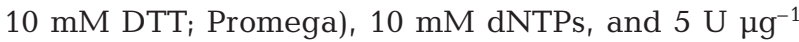
DNaase I (RNaase-free) were added and incubated for $30 \mathrm{~min}$ at $37^{\circ} \mathrm{C}$. The DNAase I was heat inactivated at $75^{\circ} \mathrm{C}$ for $5 \mathrm{~min}$. A total of $200 \mathrm{U}$ MMLV-RT was added and incubated at $42^{\circ} \mathrm{C}$ for $50 \mathrm{~min}$. The RT was inactivated at $70^{\circ} \mathrm{C}$ for $15 \mathrm{~min}$. For the second step, $1 \mu \mathrm{l}$ of the cDNA mixture was used for PCR as described above.

Southern blotting from agarose gels was done onto Hybond- $\mathrm{N}^{+}$membrane (Amersham) in sodium saline citrate buffer $\left(10 \times \mathrm{SSC}_{i} 1.5 \mathrm{M} \mathrm{NaCl} ; 0.15 \mathrm{M} \mathrm{Na}\right.$ citrate $\mathrm{pH}$ 7.0) by capillary action. Hybridization for high stringency blots was conducted in $50 \%$ formamide, $6 \times$ SSC, $5 \times$ Denhardt's, $0.5 \%$ sodium dodecyl sulphate (SDS) and $100 \mu \mathrm{g} \mathrm{ml}^{-1}$ sheared salmon sperm DNA at $42^{\circ} \mathrm{C}$. Final washes for high stringency were in $0.2 \times$ SSC, $0.1 \%$ SDS at $65^{\circ} \mathrm{C}$. Probe DNA for most Southern blots was a $1.3 \mathrm{~kb}$ PCR product obtained using 92-16 cell line DNA as a template and the 5BU and 5AL primers.

\section{RESULTS}

An analysis of ethidium bromide-stained gels of RNase-A treated but otherwise undigested genomic DNA from tumor-derived cell lines revealed the presence of a distinct DNA fragment, with a mobility equivalent to that of a $1.4 \mathrm{~kb}$ double stranded DNA, in cell line 92-16 (Fig. 1, Lanes 1 to 3). Although not observed in such high abundance in DNA from all passage levels of the 92-16 cell line, the $1.4 \mathrm{~kb}$ fragment could be reproducibly seen in all sub-cultures derived from positive cultures. A second, less abundant fragment was sometimes visible in these preparations at an apparent molecular weight of $2.6 \mathrm{~kb}$. The $1.4 \mathrm{~kb}$ fragment was isolated from agarose gels for labeling and cloning. Cloning experiments using this DNA generated an extremely low yield of legitimate inserts. Partial clones of 2 regions of this DNA were obtained by screening a damselfish tumor cDNA 
library using the $1.4 \mathrm{~kb}$ fragment as a probe. These cDNA clones were then used to design primers to amplify intervening regions of this DNA to produce PCR based probes. These PCR products were assembled to yield a partial sequence for the $1.4 \mathrm{~kb}$ fragment. This partial sequence has been deposited in GenBank (accession no. AY043182). The remaining sequence has thus far been resistant to all attempts at direct DNA and cDNA cloning or PCR and RT-PCR amplification, possibly due to secondary structure of this region of DNA. Identification of transcripts and open reading frames has not been completed, in part due to ambiguities presented by the missing sequence.

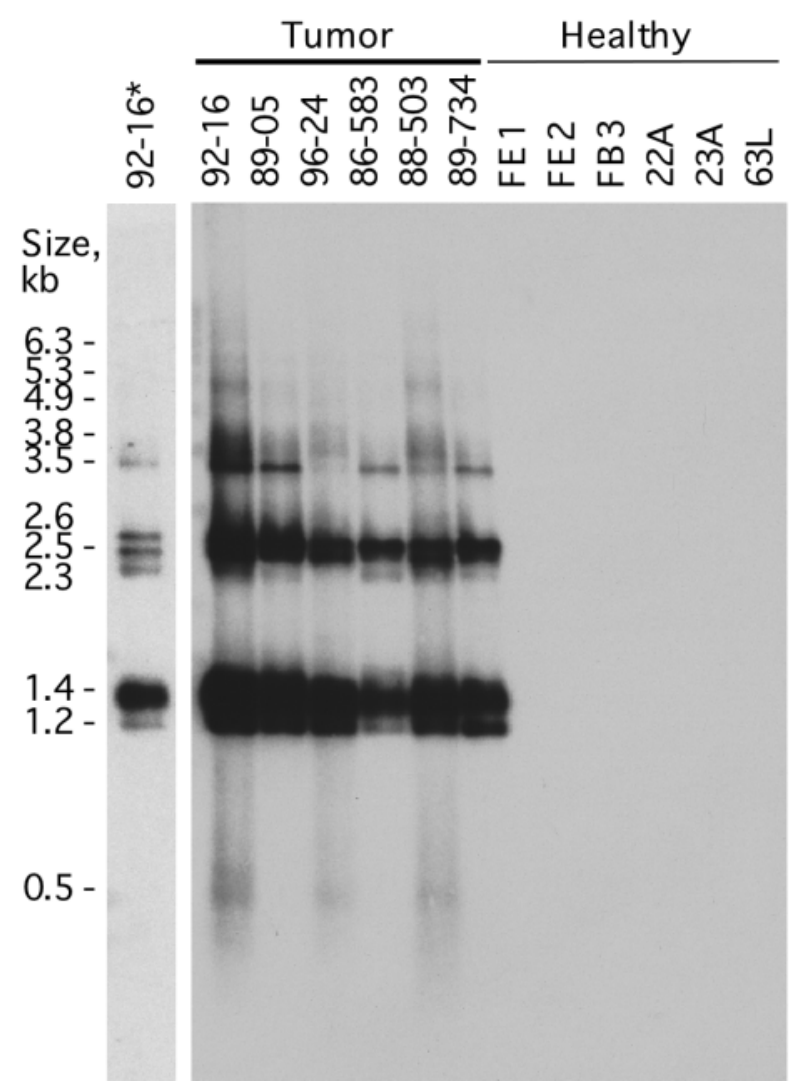

Fig. 2. Patterns of eDNA distribution in cell lines. Southern analysis of undigested genomic DNA demonstrated the presence in tumor-derived cell lines of at least 11 sizes of extrachromosomal DNA forms homologous to the $1.4 \mathrm{~kb}$ fraction shown in Fig. 1. Cell lines were derived from spontaneous (92-16, 89-05, 96-24) or experimentally induced tumors (86-583, 88-503, 89-734), normal embryos (FE1, FE2), normal brain (FB3) or normal fin cultures infected with a damselfish retrovirus (22A, 23A, 63L). Sample 92-16* was from a different culture and was exposed for less time, to better illustrate separation of similarly sized forms as well as variation in relative abundance of these forms between cultures. All samples $2 \mu \mathrm{g}$ DNA per lane, except 92-16* at $1 \mu \mathrm{g}$, samples pretreated with RNaseA. Probe DNA was a $1.3 \mathrm{~kb}$ PCR product spanning most of the $1.4 \mathrm{~kb}$ form
A series of eDNAs ranging in equivalent doublestranded size from approximately 0.5 to $7 \mathrm{~kb}$ were detected in undigested genomic DNA from all tumorderived cell lines by Southern analysis using a $1.3 \mathrm{~kb}$ PCR product (primers 5BU and 5AL) as a probe (Fig. 2). A maximum of 10 individual fragments larger than $1 \mathrm{~kb}$ could be visualized in these samples. This eDNA pattern was present in cell lines derived from both spontaneous and experimentally induced tumors. The predominant fractions in terms of copy number were 1.4 and $1.2 \mathrm{~kb}$ forms which tended to merge into a single dense band in many exposures or in samples in which some DNA degradation occurred. Larger forms were progressively less abundant as molecular weight increased. The exact number of these larger forms and their relative abundance varied somewhat between cell lines. There was no indication of forms greater than about $7 \mathrm{~kb}$ in size that would suggest that any of this sequence was integrated into chromosomal DNA. In addition, a very faint $500 \mathrm{bp}$ fragment which may be a product of degradation of the higher molecular weight forms was seen in some samples. Transcripts homologous to this vDNA were identified by application of RT-PCR to DNase treated RNA samples obtained from the 92-16 cell line. PCR products derived from a combination of vDNA primers (5BU and 5AU) indicated that transcripts as large as $1.0 \mathrm{~kb}$ were expressed in these cells.

Cell lines derived from healthy fish or embryos and cell lines derived from healthy fibroblasts infected with a damselfish retrovirus did not contain detectable DNA sequences homologous to the $1.4 \mathrm{~kb}$ fragment or PCR products derived from it (Fig. 2). An analysis of detection limits of these Southern blots was conducted based on detection of a typical single copy gene, $\beta$-actin. Using a damselfish $\beta$-actin probe, a clear signal could be detected in as little as $1 \mu \mathrm{g}$ of genomic DNA digested with Bgl II restriction enzyme (data not shown). This result indicates a predicted level of sensitivity of 1 copy per cell for blots using $2 \mu \mathrm{g}$ of DNA per sample, and 1 in 5 cells for samples where $10 \mu \mathrm{g}$ was loaded, assuming that $\beta$-actin is a single copy gene in these cells, and that the strength and hybridization efficiencies of the actin and eDNA probes were similar. An analysis of specificity of the eDNA probes compared to damselfish genomic sequences conducted under low stringency conditions (final wash at $42^{\circ} \mathrm{C}$ ) in restriction digested samples did not reveal any crosshybridization with DNA from healthy fish tissue or cell lines (data not shown). These data indicate that this eDNA is not homologous to any genomic (chromosomal or mitochondrial) sequences of the damselfish.

A similar pattern of eDNA was found by Southern analysis in tumors isolated from spontaneously diseased fish (Fig. 3). The major size fractions of eDNA 


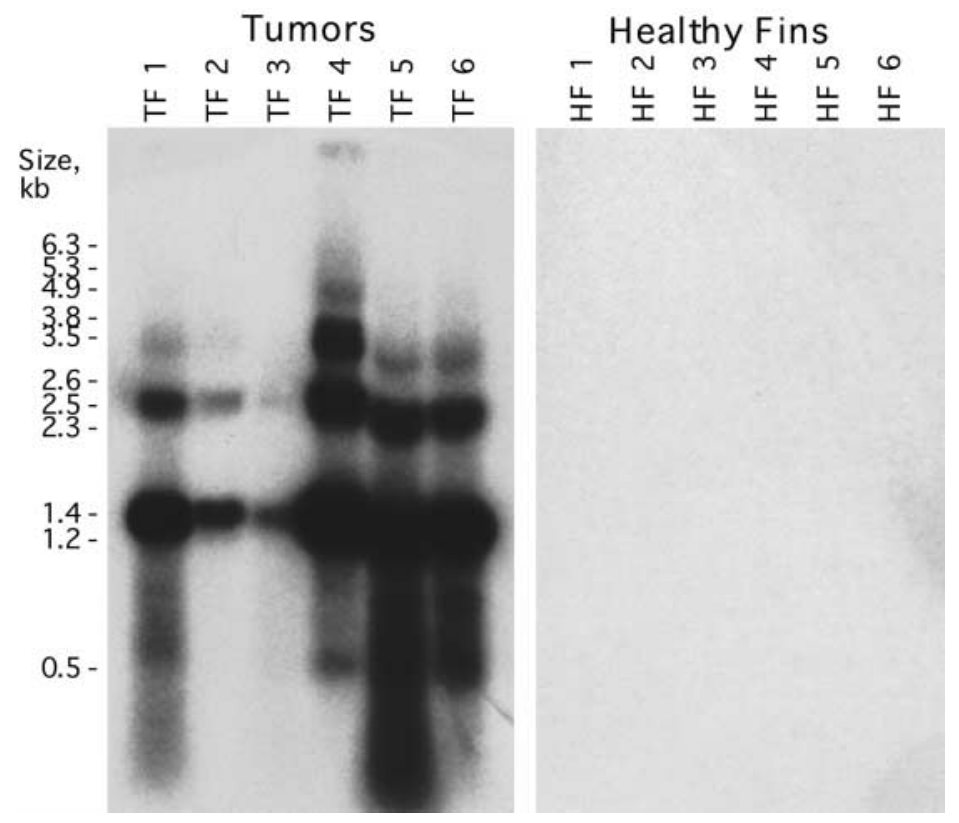

Fig. 3. eDNA in fish tissues. Southern analysis of undigested genomic DNA derived from tumors from 6 spontaneously tumored fish (TF 1-6) demonstrated a pattern of extrachromosomal DNA forms essentially identical to those observed in tumor derived cell lines (Fig. 2). No homologous sequences were detected on the same Southern blot in DNA from fins of 6 healthy fish (HF 1-6). All samples $10 \mu \mathrm{g}$ DNA per lane. Probe DNA was a $500 \mathrm{bp}$ clone from the $1.4 \mathrm{~kb}$ fragment

observed in these tumors were essentially identical to those seen in the tumor-derived cell lines, although these samples exhibited varying copy numbers of eDNA and varying amounts of degradation of DNA as evidenced by smearing of some of these forms into lower molecular weight fractions. This degradation may have been a reflection of the differing amounts of necrotic tissue often present in larger tumors. Homologous sequences were not detected by Southern analysis in genomic DNA obtained from fins of healthy fish. However, subsequent analyses based on nested-PCR have demonstrated that many healthy fish contain extremely low levels of apparently homologous DNA in some tissues (Campbell \& Schmale 2001).

The tumorigenic potential of the damselfish cell lines was assessed in vivo and compared to the distribution of eDNA homologous to that found in the 92-16 cell line, as well as to retroviral DNA. Table 1 indicates the outcome of experiments in which healthy fish were injected with whole cell preparations made from the cell lines analyzed in Fig. 2. A perfect correspondence was observed between the presence of this eDNA and the ability of tumor cell lines to induce formation of neurofibromas in vivo. In contrast, the 2 forms of the damselfish retrovirus did not show any correspondence to tumorigenicity. This relationship is strength- ened particularly by data from the 96-24 cell line which was tumorigenic but lacked detectable levels of retrovirus and the retrovirus-containing healthy fish derived cell lines, 22A, 23A and 63L, which exhibited both the 10 and $5 \mathrm{~kb}$ retroviral genomes present in most tumor lines, but lacked the eDNA forms and were not tumorigenic. Most tumorigenic cell lines exhibited a similar rate of tumorigenesis, considering the levels of variation between individual fish and the relatively small sample sizes tested for the different lines. However, the 92-16 cell line exhibited a noticeably lower rate of tumorigenesis than the other cell lines.

DNA isolated from tumors induced by IM injection of cultured tumor cells or homogenized tumors contained eDNA forms identical to those seen in tumor-derived cell lines and tumor tissues from spontaneously tumored fish (Fig. 4). In contrast, DNA isolated from unaffected fin tissue of these fish did not contain detectable eDNA. While most of these tumors contained eDNA with an identical pattern of size fragments, several tumors exhibited distinctly different patterns with higher molecular weight forms. One fish with 2 experimentally induced tumors (Fish 5, Fig. 4) exhibited a typical pattern of eDNA in 1 tumor while the other tumor contained additional, larger size fragments superimposed on this pattern. Induced tumors from 2 other fish exhibited patterns of increasing apparent abundance with increasing molecular weight and with little or no DNA of $1.4 \mathrm{~kb}$ in size, as exemplified by Fish 6 in Fig. 4. The very large size of fragments seen in the upper range of these high molecular weight patterns $(>10 \mathrm{~kb})$ suggested the possibility that some of this DNA may have been integrated rather than solely extrachromosomal.

As yet, viral particles have not been definitively identified in tissues, cultured cells or spent media from affected damselfish (other than retroviruses found in all cell lines except 96-24). To determine whether some portion of the eDNA in these samples was associated with any type of capsid or envelope, cell homogenates as well as conditioned media from cell cultures were fractionated (clarified) to eliminate intact cells and large cellular debris, and exposed to high levels of DNase $\left(80 \mathrm{U} \mathrm{ml}^{-1}\right.$ at $37^{\circ} \mathrm{C}$ for $2 \mathrm{~h}$ ) before digestion by Proteinase K and DNA extraction. As a control, a DNA sample from a tumor cell line was treated with DNase after phenol/chloroform extraction to demonstrate that this eDNA was not inherently DNase resistant (Fig. 5A).

Clarified fractions of cell homogenates contained eDNA in an identical pattern to that seen in samples prepared from whole cells (Fig. 5B). Some of this DNA 
Table 1. Association of transmissible agents in cell lines with tumorigenesis in vivo. na: time to $50 \%$ of fish tumored was not calculated if proportion tumored at 1 yr was less than $50 \% ;+,-$ presence or absence of DNA as determined by Southern blot analysis, respectively

\begin{tabular}{|c|c|c|c|c|c|c|c|c|}
\hline \multirow{4}{*}{$\begin{array}{l}\text { Cell } \\
\text { line }\end{array}$} & \multirow[t]{4}{*}{ Origin $^{a}$} & \multicolumn{4}{|c|}{$\longrightarrow$ Tumor induction ${ }^{b}$} & \multicolumn{3}{|c|}{ Agents present in cultures } \\
\hline & & \multicolumn{2}{|c|}{ Time to tumor (wk) } & \multirow{3}{*}{$\begin{array}{l}\text { Portion } \\
\text { tumored } \\
\text { at } 1 \text { yr }(\%)\end{array}$} & \multirow{3}{*}{$\begin{array}{l}\text { No. of } \\
\text { fish }\end{array}$} & \multirow{3}{*}{$\begin{array}{l}\mathrm{eDNA}^{\mathrm{c}} \\
\text { forms }\end{array}$} & \multirow{2}{*}{\multicolumn{2}{|c|}{$\begin{array}{l}\text { Retroviral } \\
\text { genomes }\end{array}$}} \\
\hline & & First & $50 \%$ & & & & & \\
\hline & & tumor & tumored & & & & $10 \mathrm{~kb}$ & $5 \mathrm{~kb}$ \\
\hline 89-05 & Spontaneous tumor & 6.6 & 25.7 & 100 & 6 & + & + & + \\
\hline $92-16$ & Spontaneous tumor & 47.1 & na & 25 & 5 & + & + & - \\
\hline $96-24$ & Spontaneous tumor & 12 & 22.1 & 100 & 8 & + & - & - \\
\hline $86-583$ & Induced tumor & 7.3 & 9.5 & 89 & 5 & + & + & + \\
\hline $88-503$ & Induced tumor & 3.1 & 14.3 & 68 & 40 & + & + & + \\
\hline $89-734$ & Induced tumor & 7 & 21 & 91 & 6 & + & + & + \\
\hline FE1 & Healthy embryos & - & - & 0 & 9 & - & + & - \\
\hline FE2 & Healthy embryos & - & - & 0 & 9 & - & + & - \\
\hline FB3 & Healthy brain & - & - & 0 & 7 & - & + & - \\
\hline $22 \mathrm{~A}$ & Healthy fin & - & - & 0 & 5 & - & + & + \\
\hline $23 \mathrm{~A}$ & Healthy fin & - & - & 0 & 6 & - & + & + \\
\hline $63 \mathrm{~L}$ & Healthy fin & - & - & 0 & 6 & - & + & + \\
\hline \multicolumn{9}{|c|}{$\begin{array}{l}\text { a Origin: induced neurofibromas produced by intramuscular injection of tumor homogenates (see Schmale 1995). Healthy fin } \\
\text { cell lines produced by infection of primary cultures with conditioned media containing retroviruses from the 89-05 or 86-583 } \\
\text { cell lines }\end{array}$} \\
\hline
\end{tabular}



Fig. 4. Detection of damselfish eDNA in experimentally induced neurofibromas. Southern analysis of undigested genomic DNA from experimentally induced neurofibromas and from grossly normal fins of the same fish (identified as tumor or fin of Fish 1-6). In addition, a second tumor was isolated from Fish 5. Samples $2 \mu \mathrm{g}$ (Fish 1-5) or $10 \mu \mathrm{g}$ (Fish 6) DNA per lane. Probe DNA was a $1.3 \mathrm{~kb}$ PCR product remained intact following DNase digestion, suggesting some type of encapsulation. Clarified and concentrated fractions of conditioned media from tumor cell lines exhibited a pattern of eDNA similar to that seen in other sample types. However, compared to the pattern seen in cultured tumor cells or tumor tissues, there appeared to be a greater relative quantity of the 2.3 to $2.6 \mathrm{~kb}$ eDNA forms in the samples of culture media (Fig. 5C). The majority of the eDNA was DNase resistant in 5 of 6 lines, although some shifts in relative abundance of these forms were observed. In 4 of 6 lines, the $1.4 \mathrm{~kb}$ form decreased while the $1.2 \mathrm{~kb}$ form increased in relative abundance and the $2.5 \mathrm{~kb}$ form appeared to shift very slightly upward in molecular weight following DNase treatment (Fig. 5D). In addition, a $500 \mathrm{bp}$ fragment present at low levels in some lines was digested by this treatment. The notable exception to this trend was the eDNA from media of the 92-16 cell line which was almost completely degraded by DNase.

\section{DISCUSSION}

Extrachromosomal DNAs in eukaryotic cells have been shown to originate from chromosomal or mitochondrial DNA as well as infecting DNA viruses or retroviruses (with a few notable exceptions such as 


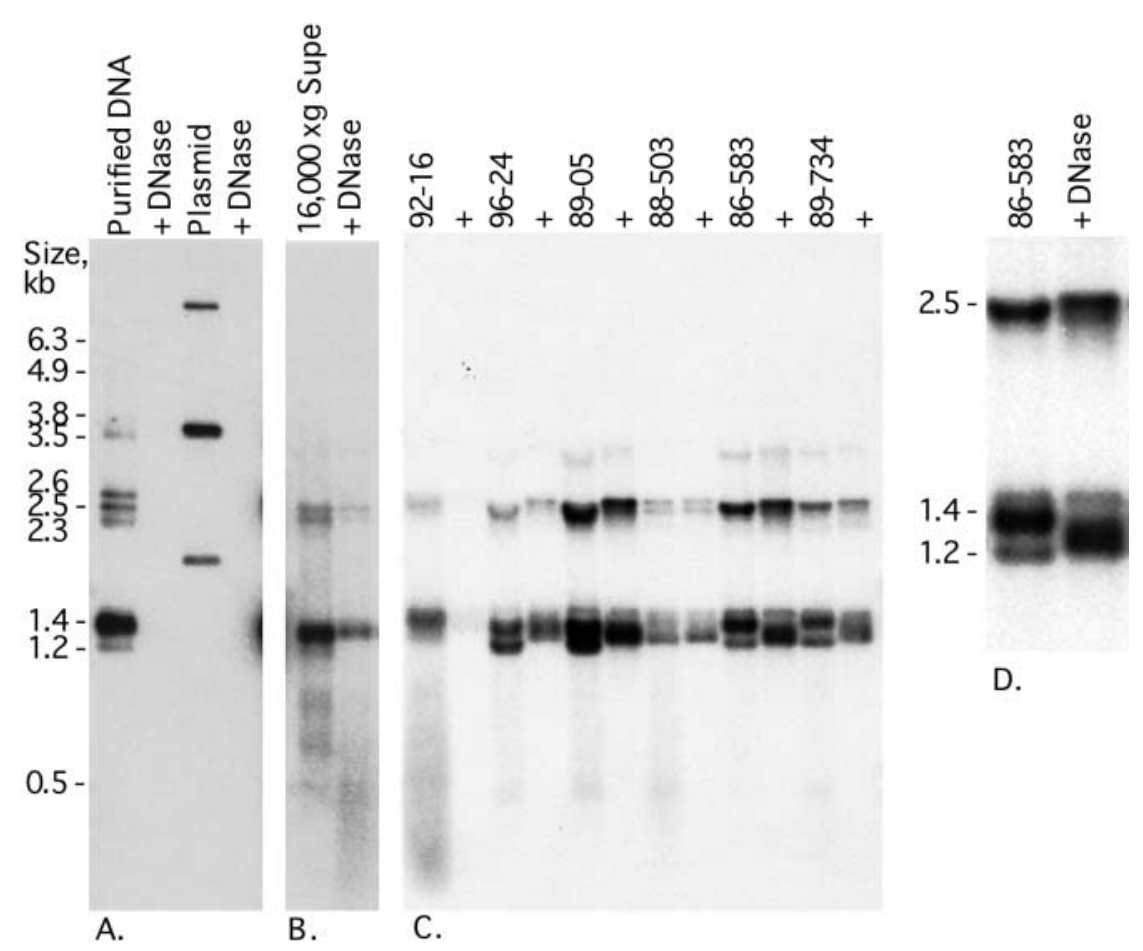

Fig. 5. DNase resistance of eDNA from tumor cells and conditioned media. All samples arranged as pairs of untreated followed by DNase treated (+) samples. (A) Control DNA from 92-16 cell line and plasmid DNA containing a 500 bp insert derived from the $1.4 \mathrm{~kb}$ form of eDNA (this plasmid was added to all DNase treated samples as an internal control for effectiveness of DNase digestion); (B) supernatants of homogenates of cells from the 92-16 tumor cell line clarified by centrifugation contain a DNase resistant form of eDNA; $(C)$ DNase resistant eDNA observed in conditioned media from tumor cell lines clarified by centrifugation followed by ultracentrifugation pelleting. Both treated and untreated samples show elevated levels of $2.5 \mathrm{~kb}$ DNA relative to 1.2 and $1.4 \mathrm{~kb}$ forms compared to DNA isolated from cells (shown in B). Only the 92-16 cell line sample exhibited significant degradation of eDNA by DNase; (D) magnification of 86-583 lanes shown in (C). DNA loaded per lane calculated as: (A) $1 \mu \mathrm{g}$ (92-16 untreated) or $2 \mu \mathrm{g}$ (92-16 DNase treated), (B) $5 \mu \mathrm{g}$ or (C) samples loaded based on equal volumes of conditioned media with each lane reflecting yield from approximately $8.7 \mathrm{ml}$ of media. Probe as in Fig. 2

DNA in unusual organelles such as plastids in apicomplexan parasites [Wilson \& Williamson 1997] or some higher plants which contain nuclear minichromosomes and other small genetic entities [Buchowicz 1997]). Chromosomal DNA is commonly amplified in tumor cells, often producing extrachromosomal DNA elements (Sanchez et al. 1998). These elements include the very large $(>1000 \mathrm{~kb})$ forms referred to as double minute chromosomes, and smaller submicroscopic molecules termed episomes or amplisomes (Pauletti et al. 1990). The amplified genes present in these elements often convey a selective growth advantage on these cells and sometimes include multidrug resistance genes (Sanchez et al. 1998). An additional phenomenon observed in both normal and transformed cells is the formation of small polydisperse circular DNA (Cohen \& Lavi 1996). These relatively small $(<10 \mathrm{~kb})$, extrachromosomal, circular DNAs can be induced by exposure to chemical carcinogens and may be formed as inverted repeats as a result of aberrant replication of chromosomal DNA. Thus, a wide variety of eDNA elements derived from chromosomal DNA can be found in eukaryotic cells, particularly tumor cells. However, the lack of homology observed between the eDNA observed in the damselfish tumors and normal cellular DNA demonstrates that this is not amplified chromosomal (or mitochondrial) DNA. Thus, this eDNA must be of exogenous origin. This leads to the central questions of whether these sequences constitute the genome of a virus and if this virus is the etiologic agent of DNF.

As yet, viral particles have not been confirmed in tumor tissues or tumor-derived cell lines from bicolor damselfish (other than the retroviruses detected in both tumor and healthy fish derived cell lines). However, the presence of DNase resistant forms of eDNA in cell homogenates as well as in conditioned media indicates that these sequences are protected from degradation by some type of capsid or envelope. Control experiments have shown that this eDNA is not inherently resistant to digestion by DNase when purified away from proteins and cellular components. The most logical explanation for these results is that the DNase resistant sequences are packaged into viral particles. 
A similar DNase-based approach has been used to quantify numbers of intact particles of adeno-associated virus as distinct from viral DNA not protected in particles (Clark et al. 1995).

The genomes of most DNA viruses and retroviruses are detectable in the nuclei as eDNA during at least a portion of the viral life cycle (Fields et al. 1996). Infected cells often contain complex patterns of different size viral eDNAs which reflect various stages in replication of the viral genome (Snapka 1987, Cotmore \& Tattersall 1998). These patterns are produced by pauses in replication which result in the accumulation of discrete size fractions of DNA rather than simply a continuum of sizes of elongating DNA (Snapka 1987). In addition to extrachromosomal forms, some DNA viruses and all retroviruses also exhibit integrated stages where one or more viral genomes are integrated into chromosomal DNA. The pattern of multiple size fractions of apparently non-endogenous eDNA observed in tumor cells in DNF is consistent with the pattern expected from a DNA virus. The apparent lack of integrated homologous DNA in tissues or cultured cells suggests that this agent probably does not belong to a group with an obligate integrated stage, such as the retroviridae. At this time we are referring to this suspected virus as the damselfish virus-like agent (DVLA).

Replicative intermediates of viral genomes can represent whole or partial multiples, up to several times the unit genome length, and typically consist of mixtures of single and double stranded DNA. While the smallest form of eDNA typically corresponds to the unit genome length, interpretation of relative sizes of these forms from non-denaturing gels can be complicated by the different mobilities of linear, relaxed circular and supercoiled forms of the same sequences. Preliminary analysis of DVLA DNA present in damselfish cells has indicated that the 2.3 to $2.6 \mathrm{~kb}$ sequences may represent double stranded equivalents of the 1.2 and $1.4 \mathrm{~kb}$ forms and that forms larger than $2.6 \mathrm{~kb}$ may be complex multimeric repeats with considerable secondary structure (data not shown). This suggests that the size of unique DNA present in the genome of this agent is approximately $2.5 \mathrm{~kb}$ of dsDNA. This relatively small genome size would rule out a relationship of this agent to most known DNA viruses which have much larger genome sizes ( $>4 \mathrm{~kb}$ dsDNA). Only circoviruses (1.7 to $2.3 \mathrm{~kb}$ ssDNA), hepadnaviruses (3.2 kb partially dsDNA) and parvoviruses (5 kb ssDNA) exhibit DNA genomes in this size range (Fields et al. 1996).

Preliminary comparisons of partial sequences of the damselfish agent have not revealed any similarities to known viruses or other sequences deposited in GenBank (data not shown). Determination of the relationship of DVLA to other virus families (as well as deter- mination that this agent is actually a virus) will require completion of DNA sequence, transcript and viral protein analyses as well as documentation of morphology of viral particles.

The basis for proof of causality of disease by a specific agent traditionally relies on fulfillment of the postulates set forth by Robert Koch in the late 1800s as modified by Rivers, and others (reviewed by Fredricks \& Relman 1996). While this approach remains a cornerstone of microbiology, the difficulty of cultivating many viral agents in vitro and particularly in assuring that cultures or tissue isolates are free of microorganisms other than the ones being investigated has complicated studies of disease etiology. Many viral infections are cryptic with few viral particles visible intracellularly (Tooze 1980). This is especially true in the case of oncogenic viruses which typically exist at low copy numbers or are defective for replication in tumor tissues (Nevins \& Vogt 1996). In such cases, identification of etiologic agents may rely heavily on determination of distribution of microbial nucleic acid sequences rather than manipulation of cultured microbes (Fredricks \& Relman 1996).

Damselfish neurofibromatosis has previously been shown to be transmissible by a sub-cellular, filterable agent (Schmale 1995). The differential distribution of DVLA DNA in tumor-derived versus normal tissues and cell lines, the higher prevalence of infected fish observed on reefs with high versus low DNF prevalence (Campbell \& Schmale 2001) and the correlation between tumor development and increasing copy numbers per cell of DVLA DNA during progressive stages of development of DNF (Campbell et al. 2001) suggest a potential causal relationship of this agent with DNF. The hypothesis that DVLA is the etiologic agent of DNF is further supported by the perfect correlation of the presence of this eDNA in cell lines with the ability of these lines to induce tumors when injected into healthy damselfish. This relationship is also strengthened by the observation that DNase resistant, presumably encapsulated, extracellular DVLA DNA is present in conditioned media from the 5 rapidly tumorigenic cell lines but is relatively rare in the 1 line, 92-16, which causes tumors at much slower rates. An additional key piece of evidence of a causal relationship between this agent and DNF is the appearance of an identical pattern of eDNA in experimentally induced tumors (the lack of detectable DVLA DNA in the fin samples from these fish also suggests that these sequences were either absent or rare, present at much less than 1 copy per cell, before the fish were injected). Although neither the tumor tissues nor the cell lines used to induce tumors can be shown to be free of other sub-cellular agents, this is a typical limitation in studies of viral pathogenesis. Given this limita- 
tion, we believe that these data fulfill the basic requirements of Koch's postulates for causality, indicating that the DVLA is most likely the etiologic agent of DNF.

Studies of oncogenic viruses have contributed greatly to knowledge of mechanisms of carcinogenesis including the discovery of oncogenes and tumor suppressor genes and an understanding of how alterations in the activity of such genes lead to cell transformation. Studies of the 2 most common neoplastic syndromes involving Schwann cells in humans, neurofibromatosis types 1 and 2, have revealed that some of the mechanisms which control proliferation of this cell type may be significantly different than those in most other cell types (Bollag \& McCormick 1991). At this time, DNF appears to be the only example of a transmissible tumor involving Schwann cells (as well as chromatophores). This unique aspect of DNF suggests that the etiologic agent of this disease may be a useful tool for investigation of the mechanisms responsible for neoplastic transformation of these cell types.

Acknowledgements. Special thanks are extended to Saul Cacal for assistance in cell culture, and Lynne Fieber, Saul Cacal and Sean Baribeau for assistance with collection of fish. Fish were collected under research permits issued by the State of Florida, Department of Environmental Protection, the Biscayne National Park (National Park Service) and the Florida Keys National Marine Sanctuary (National Oceanic and Atmospheric Administration). Thanks are extended to the personnel of the Florida Keys National Marine Sanctuary and the Biscayne National Park for logistical support. This research was supported by PHS grants NS36998 and ES05705.

\section{LITERATURE CITED}

Bollag G, McCormick F (1991) Differential regulation of rasgap and neurofibromatosis gene-product activities. Nature 351:576-579

Campbell CE, Schmale MC (2001) Distribution of a novel infectious agent in healthy and tumored bicolor damselfish in Florida and the Caribbean. Mar Biol 139: 777-786

Campbell CE, Gibbs PDL, Schmale MC (2001) Progression of infection and tumor development in damselfish. Mar Biotechnol 3:S107-S114

Clark KR, Voulgaropoulou F, Fraley DM, Johnson PR (1995) Cell lines for production of recombinant adeno-associated virus. Hum Gene Ther 6:1329-1341

Cohen S, Lavi S (1996) Induction of circles of heterogeneous sizes in carcinogen-treated cells: two-dimensional gel analysis of circular DNA molecules. Mol Cell Biol 16: 2002-2014

Cotmore S, Tattersall P (1998) High-mobility group 1/2 proteins are essential for initiating rolling-circle-type DNA replication at a parvovirus hairpin origin. J Virol 72: $8477-8484$

Editorial responsibility: Jo-Ann Leong,

Corvallis, Oregon, USA
Fan H (1994) Retroviruses and their role in cancer. In: Levy JA (ed) The Retroviridae, Vol 3. Plenum Press, New York, p 313-362

Fields B, Knipe D, Howley P (1996) Fields virology. Lippincott-Raven, Philadelphia, PA

Fredricks DN, Relman DA (1996) Sequence-based identification of microbial pathogens: a reconsideration of Koch's postulates. Clinical Microbiol Rev 9:18-33

Holzschu D, Martineau D, Fedor S, Vogt V, Bowser P, Casey J (1995) Nucleotide sequence and protein analysis of a complex piscine retrovirus, Walleye Dermal Sarcoma Virus. J Virol 69:5320-5331

LaPierre LA, Casey JW, Holzschu DL (1998) Walleye retroviruses associated with skin tumors and hyperplasias encode cyclin D homologs. J Virol 72:8765-8771

Nevins J, Vogt P (1996) Cell transformation by viruses. In: Fields BN, Knipe DM, Howley PM (eds) Fields virology, 3rd edn. Lippincott-Raven, Philadelphia, PA, p 301-344

Pauletti G, Lai E, Attardi G (1990) Early appearance and long-term persistence of the submicroscopic extrachromosomal elements (amplisomes) containing the amplified DHFR genes in human cell lines. Proc Natl Acad Sci USA 87:2955-2959

Poulet FM, Bowser PR, Casey JW (1994) Retroviruses of fish, reptiles, and molluscs. Levy JA (ed) The Retroviridae, Vol 3. Plenum Press, New York, p 1-38

Sambrook J, Fritsch EF, Maniatis T (1989) Molecular cloning, a laboratory manual. Cold Spring Harbor Laboratory Press, New York

Sanchez A, Barrett J, Schoenlein P (1998) Fractionated ionizing radiation accelerates loss of amplified MDR1genes harbored by extrachromosomal DNA in tumor cells. Cancer Res 58:3845-3854

Schmale MC (1991) Prevalence and distribution patterns of tumors in bicolor damselfish (Pomacentrus partitus) on South Florida reefs. Mar Biol 109:203-212

Schmale MC (1995) Experimental induction of neurofibromatosis in the bicolor damselfish. Dis Aquat Org 23: 201-212

Schmale MC, Hensley GT (1988) Transmissibility of a neurofibromatosis-like disease in bicolor damselfish. Cancer Res 48:3828-3833

Schmale MC, Hensley GT, Udey LR (1983) Multiple schwannomas in the bicolor damselfish, Pomacentrus partitus; a possible model of von Recklinghausen neurofibromatosis. Am J Pathol 112:238-241

Schmale MC, Hensley GT, Udey LR (1986) Neurofibromatosis in the bicolor damselfish, (Pomacentrus partitus) as a model of von Recklinghausen neurofibromatosis. Ann NY Acad Sci 486:386-402

Schmale MC, Gill KA, Cacal SM, Baribeau SD (1994) Characterization of Schwann cells from normal nerves and from neurofibromas in the bicolor damselfish. J Neurocytol 23:668-681

Schmale MC, Aman MR, Gill KA (1996) A retrovirus isolated from cell lines derived from neurofibromas in bicolor damselfish. J Gen Virol 77:1181-1187

Snapka RM (1987) Topoisomerase inhibitors can selectively interfere with different stages of simian virus 40 DNA replication. NCI Monogr 4:55-60

Tooze J (1980) DNA tumor viruses. Cold Spring Harbor Publishers, Cold Spring Harbor, NY

Wilson RJ, Williamson DH (1997) Extrachromosomal DNA in the Apicomplexa. Microbiol Mol Biol Rev 61:1-16

Submitted: February 28, 2001; Accepted: October 13, 2001

Proofs received from author(s): April 19, 2002 